\title{
ICT for External Stakeholder Management: Sociomateriality from a Power Perspective
}

\author{
Johan Ninan ${ }^{\mathrm{a} *}$, Ashwin Mahalingam ${ }^{\mathrm{b}}$, Stewart Clegg ${ }^{\mathrm{c}, \mathrm{d}}$ and \\ Shankar Sankaran
}

${ }^{a}$ Bartlett School of Construction and Project Management, University College London, London, UK, ${ }^{b}$ Department of Civil Engineering, Indian Institute of Technology Madras, Chennai, India; ${ }^{c}$ Business School, University of Technology Sydney, Sydney, Australia; ${ }^{d}$ Nova School of Business and Economics, Carcavelos, Portugal; ${ }^{e}$ School of Built Environment, University of Technology Sydney, Sydney, Australia

*Corresponding author - Johan Ninan, e-mail - Johan.Ninan@gmail.com

\begin{abstract}
$\underline{\text { Abstract }}$
External stakeholder support is critical to the success of megaprojects, necessitating strategic engagement, often using Information and Communications Technology (ICT). We conducted 30 semi-structured interviews with a megaproject team and analysed their social media communications with the project community. The findings show three ICT practices used for managing external stakeholders: visualization, simulation and social mediatization. Taking a sociomateriality lens we demonstrate how these practices are used for diverse unintended uses to manage external stakeholders. Anchored in a dimensions of power framework, we discuss how these ICT practices were strategically used for persuading, framing and hegemonizing external stakeholders in megaprojects. Theoretically, we highlight the role of ICT for managing external stakeholders over the current use of improving the competitive advantage of internal stakeholders. Practically, social media is used to articulate practices in all the strategic roles, positioning it in a role as a critical ICT tool for external stakeholder management in infrastructure megaprojects.
\end{abstract}

Keywords: Megaprojects; ICT in construction; Strategies; External Stakeholders; Dimensions of Power

Cite as: Ninan, J., Mahalingam, A., Clegg, S., \& Sankaran, S. (2020). ICT for external stakeholder management: sociomateriality from a power perspective. Construction Management and Economics. https://doi.org/10.1080/01446193.2020.1755047 


\section{Introduction}

Megaprojects are a different breed of projects compared to conventional projects because of their peculiar qualitative characteristics represented by the 6Cs: they are Colossal, Captivating, Complex, Controversial, Costly, and laden with Control issues (Frick, 2008). Quantitatively, megaprojects are defined as projects that cost more than one billion USD (Flyvbjerg, 2014). The history of these megaprojects provides a litany of poor performance in terms of budget and duration projections (Flyvbjerg et al., 2003), as their specific characteristics pose multiple risks for issues in one area that can cascade into others and escalate as significant failures (Little, 2011).

One of the significant issues likely to prove problematic is the challenge of managing multiple stakeholders, something exacerbated when the stakeholders are located externally to the megaproject, rather than being internal representatives with contractual commitments. External stakeholders, such as existing landowners, utilities and the community surrounding the project site, are not bound by contractual instruments and operate across highly permeable boundaries (Mahalingam \& Ninan, 2019) but typically do not have representation in megaproject decision-making. Nonetheless, their consent is often necessary if the megaproject is to unfold without resistance and friction, especially when complexity is aggravated because the project team is dependent on external stakeholders for project completion, often in the absence of any reciprocal dependence. Such dependency can lead to external stakeholders demanding compensation in return for cooperation (Giezen, 2012) or refusing to cooperate by resisting publicly (Lehtonen, 2019; van den Ende \& van Marrewijk, 2019). Complying with external demands can lead to scope creep, goal displacement, escalation of commitment and campaigns of active civil disobedience and resistance (Ninan et al., 2019; Jordhus-Lier, 2015), factors frequently cited as causes for under- 
performance in megaprojects (Gil, 2015). In the absence of governance mechanisms such as mutually agreed contracts or conformance to a set of standards, project teams must endeavour to manage these external stakeholders strategically (Ninan et al., 2019). The literature on external stakeholder management discusses the use of Information and Communication Technology (ICT) for engaging with stakeholders (Walker et al., 2008; Atkin \& Skitmore, 2008). However, ICT has multiple implications and can be used for different purposes in different contexts as explored in the sociomateriality of ICT (Leonardi \& Barley, 2010). This nuanced view of ICTs as being used for different strategic purposes has currently not been explored sufficiently in the context of managing external stakeholders. These different strategic purposes of ICT can be understood from an organizational power theoretical perspective because power can help make sense of strategic action (Hardy, 1996); in a formulation, one might say that "Strategy = Knowledge + Capability (or the power) to accomplish things" (Clegg et al., 2020). Thus, this research seeks to explore the diverse strategic uses of ICT as a capability for using different forms of knowledge to manage external stakeholders by seeing sociomateriality from a power perspective. To do so, we first introduce research on ICT in the construction industry before relating strategic action to the multidimensionality of power premised on the dimensions of power framework (Lukes, 2005). We then use a case study of a metro-rail megaproject in India to understand the ways in which ICTs were used to manage external stakeholders. We conclude by developing a framework to explain the strategic use of ICTs for managing external stakeholders based on the dimensions of power framework.

\section{ICT in the Construction Industry}

The use of ICT in construction integrates computing technology and information processing in the construction process (El-Ghandour \& Al-Hussein, 2004). Rather than 
being a single technology, ICT is an umbrella term which refers to a wide range of technology applications used to address diverse issues in the industry via the communication of information (Nandyala \& Kim, 2016). ICT applications in the construction industry, originally started from word processing, moved to Internet communications, coordination and cost control (Oladapo, 2007) and have expanded to the use of Radio Frequency Identification (RFID), Building Information Modelling (BIM), Mobile computing, and Augmented Reality (AR) (Alsafouri \& Ayer, 2018). ICT also includes computing technology employed in decision making by considering different parameters such as cost implications, strategic preferences, etc. (Arashpour et al., 2018). In spite of the many advantages of ICT implementation, such as enhancing the ability to enhance productivity by automating work practices and making decisions using automated information search, the construction industry has been criticized for insufficient and slow adoption of ICT over recent decades, compared to other industries (Hosseini et al., 2013).

Perceived operational barriers to ICT adoption include the fragmented nature of the industry, limited budgets for ICT investments, lack of support from management, lack of commitment from other project participants, low user acceptance as well as employee learning issues (Taylor \& Levitt, 2007). In addition to the operational efficiencies that ICT is expected to enable during the construction phase, the literature also emphasizes the strategic role ICTs can play in achieving organization goals. For instance, ICT in the form of simulations is used in participatory modelling (PM) for engaging with external stakeholders (Hedelin et al., 2017). Such an interactive and iterative process has been used to solve wicked problems through joint decision making with those negatively affected (Davies et al., 2015). Evers et al. (2016) note the use of 
such participatory modelling in flood risk management through the use of maps presented in Google Earth.

The use of ICT in construction fosters trust, transparency, interest and thereby acceptance of measures proposed by the participating stakeholders, according to Gooch and Huitema (2008) while, according to Nitithamyong \& Skibniewski (2006), ICT enabled strategies can improve the competitive advantage of the contractor, thereby attracting more sophisticated clients and enhancing the organization's image. Walker et al. (2008) noted how ICT is used strategically to visualize external stakeholders, understand their influence and create stakeholder maps. Such clear pictures of stakeholder influence patterns have been seen to contribute to reducing the chances of project failure (Atkin \& Skitmore, 2008). Specifically studying the role of 4D Computer Aided Design (CAD) in communicating construction plans to the client, Mahalingam et al. (2010) showed how it helped project participants to visualize the schedule, make suggestions and approve or disapprove design features. Building Information Modelling (BIM), used opportunistically by clients with more technical knowledge, compared to contractors and suppliers, creates reverse information asymmetry according to Forsythe et al. (2015).

While ICTs have been shown to be used to engage external stakeholders in the construction industry, analysis of the role of ICT in engaging with these stakeholders as well as inquiry into how they have an impact on the project requires more understanding in terms of when and how ICT is used. In this context, Orlikowski \& Iacono (2001) suggested that management scholars should seriously consider the effects, context and capabilities of ICT - a sociomateriality perspective that we now turn to. 


\section{Sociomateriality and ICT}

Styhre (2017) claims that the construction management research community needs to adopt perspectives such as sociomateriality that are influential in the broader management domain. Defining sociomateriality, Orlikowski (2010) highlighted three perspectives on organizing interactions between people and technology in management research. She called the first perspective 'absent presence' where technology is unacknowledged by organizational researchers and thereby not part of their study, a situation that Barad (2003) had earlier remarked on in the following terms - that for organizational studies 'the only thing that does not seem to matter anymore is matter.' In the second perspective discussed by Orlikowski (2010), technology is regarded in organizationally familiar terms as an 'exogenous force', a powerful driver having determinate impacts on organizational life. Technology is seen as 'hardware' separate from agencies but having a direct impact on human behaviour in terms of their autonomous, context-less, predictable and stable materialities. Considering the situated nature of technology, Orlikowski (2010) highlights a third perspective on materialities as 'emergent process', in which technology is positioned as a product of ongoing interactions of human choices, actions, social histories and institutional contexts. The social and material are entangled in multiple and dynamic ways in everyday life, a perspective that shifts from abstract and general understanding of technology to one grounded in the ways in which people engage with historical and social contexts.

The social construction of technology and its effects was advanced by Barley (1986) in his study of the implementation of Computed Tomography (CT) scanning technology in two different hospitals. He observed that different users engage differently with the same technology rather than the technology having determinate effects. Similarly, Leonardi \& Barley (2008) noted how technologies are used is a 
product of negotiations, human agency and personal interest. Highlighting the contextual use of technology, Orlikowski and Iacono (2011) drew on the example of 'being on the internet' as differing for users in China from users in the United States, confirming that the social and technological are both ontologically inseparable (Orlikowski \& Scott, 2008) and entangled as a sociomaterial assemblage (Wagner et al., 2011) of users and technology. Such sociomaterial entanglement frames the meaning of the material in everyday practice (Suchman, 2007), producing intended as well as unintended outcomes in practices both prescribed and imagined otherwise (Orlikowski $\&$ Scott, 2008) through exploiting affordances (Leonardi \& Vaast, 2017). Diverse social and cultural studies (Lamprou et al., 2014) stress that the same technologies can be recontextualized differently in practice. Thus, identical ICT technologies can trigger different dynamics and outcomes, depending on the intricacies of the social context (Leonardi \& Barley, 2010) in which they operate.

Collinge (2018) highlights how artefacts such as drawings, digital imagery, physical objects, etc., can be used as resources critically affecting stakeholder engagement. If technologies are neither neutral affordances nor determinant of predictable outcomes, then we must attend to the contextual realities of the situations in which they are deployed. From a sociological perspective, the defining quality of contextual reality is the power relations inscribed therein: it is these that articulate, frame and dominate action expressed in the entanglements of humans, technologies and other materialities (Clegg, 1989). Power relations can be viewed from many diverse perspectives; it is to an influential expression of these that we turn next, which is particularly salient for analysis of the multiple and emergent uses of ICT when managing external stakeholders in megaprojects. In order to understand the diverse recontextualizations of ICT, understood as a "specialist application of Information 
Technology that has some aspect of communication" in it (Designingbuildings.co.uk, 2017), along with the intended and unintended outcomes (Orlikowski, 2008) that emerge from its strategic use, we turn to the dimensions of power framework (Lukes, 1974; 2005). Such a dimensions of power framework can be used to make sense of different strategic actions (Hardy, 1996) employed in external stakeholder management.

\section{Dimensions of Power}

Power, oddly, is often neglected in the governance literature (Arts \& Tatenhove, 2004); we say oddly because, of course, to govern is to yield power whether done so in public or private interests. One of the most influential early social science definitions of power was provided by Max Weber who sees it as "the probability that one actor within a social relationship would be in a position to carry out his own will despite resistance" (Weber, 1947). Based on this definition, we can begin to explore the capacity of ICT as a materiality and medium for 'carrying out the will' of the construction project team in relation to the demands of external stakeholders. Of course, if power were only a matter of will being paramount, it would be relatively simple to research it through episodes of concrete decision-making (Dahl, 1961). However, the prevalence of mobilizations of bias, of issues and non-issues, leading not only to decision-making but also nondecision-making (Bachrach \& Baratz, 1962) make the empirical observation of 'will' problematic.

Lukes $(1974 ; 2005)$ famously devised a three dimensional 'radical' framework for analysis of the 'essentially contested' (Lukes, 2005) concept of power. With regard to power's conceptual contestation in the literature, Haugaard (2010) argues that various expressions display 'family resemblances.' They are related concepts of power, for which there is no single best definition as the definition changes, depending upon the context in which it is applied. Thus, the concept of power encompasses a broad set of 
definitions. In the past, several major attempts to map the different forms of power have been made (Lukes, 1974; 2005; Clegg, 1989; Fleming \& Spicer, 2014). A common distinction is between power's overt exercise and that which is covert. Overt power involves the direct exercise of power and we can observe this easily when one agency manages to make some other agency do as it wills. Covert power, however, cannot be so easily observed as it is condensed in enduring institutional structures (Clegg, 1989).

Lukes' first dimension of power - overt power - involves the direct mobilization of will, which builds upon Dahl's (1957) concept of power as providing 'one with the ability to make another do something they would not otherwise do.' The execution of this overt form of power relies on the actor's ability to mobilize resources to realize certain goals (Avelino, 2011). It is an instrumental perspective that views power as an actor-specific resource used in pursuit of self-interest (Avelino \& Rotmans, 2009). Thus, power in the first dimension is overt and the possession of resources affords the actor the ability to influence decision making.

The second dimension of power is a mix of overt and covert power and thus involves direct and indirect mobilization of power. Commonly known as the power of non-decision making, this construct was developed by Bachrach and Baratz (1962) as they highlighted the role of agenda-setting by elites, whose biases mobilize agendas and issues (Schattschneider, 1960) and their ability to keep topics off the agenda by framing agendas on an exclusionary basis. Scholars argue that in agenda-setting there is no direct exercise of resource-based power; instead, there is an implicit shaping of issues considered important or relevant in relation to their inclusion or exclusion from agendas (Fleming \& Spicer, 2014). Being able to set the agenda is referred to as 'real power' by Lukes (2005) because it enables issues to be framed as legitimate and enacted or not and thus limits not only those issues addressed but also the range of possible solutions that a 
broader set of issues might engender. Thus, power in the second dimension involves the actor's ability to keep topics of the agenda and thereby prevent decisions that are against the agent's interest.

The third dimension of power is covert, the radical view of power proposed by Lukes (2005), which is assumed to work by shaping subjects' preferences, attitudes, and political outlook concerning what they define as being in their interests through subjects accepting situations as an existing order of things for which no alternative is imaginable (Lukes, 2005). In organizational terms, senior managers can aspire to create such a state of order through designing specific corporate cultures as well as drawing on field-wide or societal-wide assumptions to buttress their authority and that culture they seek to communicate (Fleming \& Spicer, 2014; Alvesson \& Karreman, 2000); more radically still, the assumption is that when those subject to 'hegemonizing' attempts embrace them, unaware of their 'real interests' in not doing so, then they are wholly subordinated in terms of the third dimension of power (Clegg, 1989). Thus, power in the third dimension involves the ability to shape people's perception and preferences concerning their interests such that an alternative becomes unimaginable. The three dimensions of power adapted from Lukes (2005) are depicted in Figure 1.

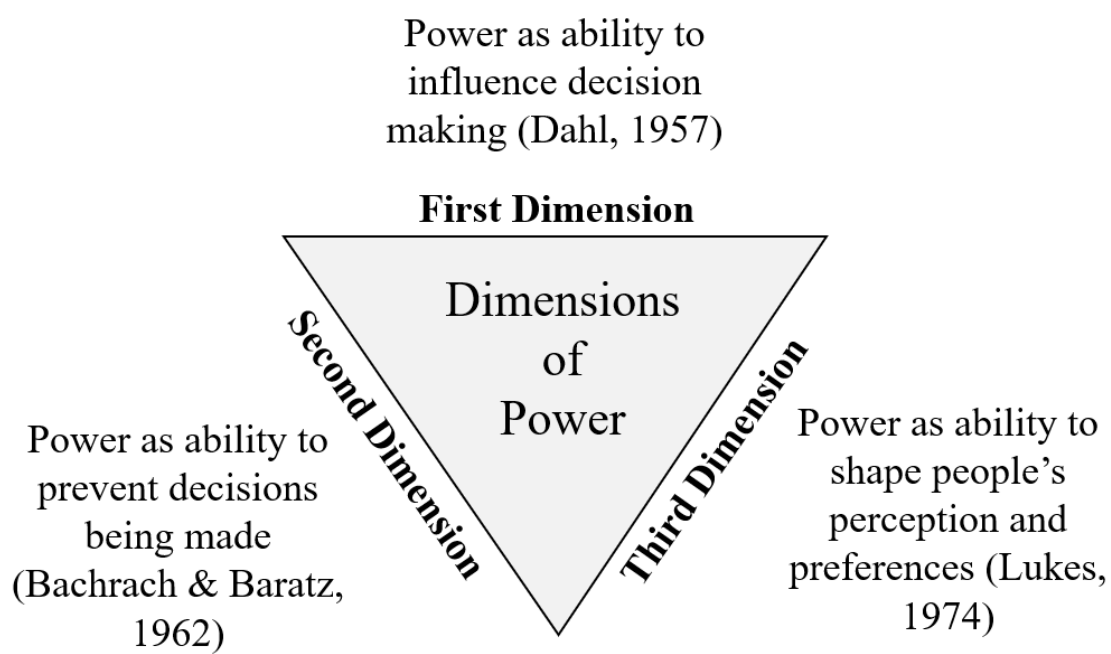


Figure 1. Dimensions of power framework - adapted from Lukes (2005)

The dimensions of power framework (Lukes, 2005) can be used to understand how power is mobilized through overt, combined and covert dimensions in ICT practices while managing external stakeholders. These dimensions can be activated in various ways through the presence of ICTs, in efforts to shape the outcomes of stakeholder management. Our intent in analysing such attempts and efforts leads to two specific research questions (1) What forms of ICT are used to manage external stakeholders overtly and covertly? (2) In terms of the dimensions of power framework, what uses of ICT align with which dimensions? These questions frame the analysis of data collected from a megaproject in India, using a case study approach, to explain the strategic role and use of ICTs in the megaproject.

\section{Research Approach}

In this section, we discuss the research methodology as in 'why we did' and the research method as in 'what we did' (Chan, 2020). The aim of this research is to explore how ICT enables the strategic practices used to manage external stakeholders. In doing this, qualitative inductive research is apt because it allows the researcher to start with participant's views, to construct patterns from these using inferences from appropriate conceptual frameworks and create theory on this basis. Bansal et al. (2018) highlight that inductive theorizing grounded in data can broaden the researchers' epistemological frame, yielding completely novel ideas. Within qualitative methods, a case study approach is appropriate in exploratory research where the aim is to gain familiarity with a problem or to generate new insights for future research (Eisenhardt, 1989; Flyvbjerg, 2006) as well as a deeper understanding of the context being studied (Dyer \& Wilkins, 1991). Single cases provide excellent opportunities to enhance contextual understanding because of their depth in data collection and analysis (Lundin \& Steinthorsson, 2003). 
Any single organizational study may, in fact, afford opportunity for a compendium of mini cases showing the diversity of the phenomenon in question (Ragin, 1992). The case study in question was carried out to optimize understanding of diverse strategic uses of ICT for stakeholder management within the case rather than to generalize beyond it (Stake, 2005).

The case selected is an infrastructure megaproject in India. The project is the first phase of a metro rail project budgeted to cost 2.2 billion USD. All the special characteristics which qualitatively qualify it as a megaproject are present: it is being built in an existing city, disrupting many services, requiring coordination across a vast range of stakeholders and being subject to considerable pressure to maintain schedule. India being a democratic setting requires external stakeholders to be managed, be it for land acquisition or community who are affected by the noise, vibrations and disturbances (Ninan et al., 2019). The project also used ICTs to interact with external stakeholders as stated by the public relations officer,

"We are actually very active on social media network sites, Facebook page, Twitter page ... We are planning to open up a snap chat."

Thus, we selected this project for theoretical reasons (Yin, 1984): the presence of multiple external stakeholders, disruption of services requiring the need to manage them, and the use of ICT to manage them.

Semi-structured interviews with the project team were used to explore overt strategies through which the megaproject sought to manage external stakeholders. We conducted semi-structured face-to-face interviews with project personnel. Only the project team was interviewed as our aim was to understand the ICT enabled strategies used by the project team to manage external stakeholders; thus, we were not researching 
the efficacy of the strategic practices so much as their mobilization as capabilities enacted by the project. We asked the project team open-ended questions about how they managed external stakeholders. We asked them follow-up questions when they quoted the use of any form of ICT for managing external stakeholders, which helped us get more information on the sociomateriality in practice. A total of 30 interviews were conducted with 26 participants which together added up to 29 hours of interview data. We compared comments made by the participants and conducted a second round of interviews with four participants thereby increasing internal consistency and validity of our data (Yin, 1984). In exploring covert strategies, analysis was made of the ways in which the project used strategic discourses to communicate with the external stakeholders through social media. The project team maintained and was active in social media networks such as Facebook, Twitter, and Instagram. Their official Twitter page had 6,208 followers, and their Facebook page had 240,970 followers as of 14th August 2018. We studied the interactions of the metro rail organization with the community to understand the role of social media as an ICT in managing external stakeholders. We recorded 641 tweets from twitter from April 2012 (date of the first post) to August 2017. We also studied 510 posts on Facebook from May 2017 to October 2017 that included the metro rail organization's posts as well as comments from the wider community. The social media communications were analysed, based on the contextual meaning of the text.

To analyse the data collected, we used a grounded theory approach (Strauss \& Corbin, 1990). Grounded theory is an inductive research process that is effective in transforming raw data into theoretical concepts (Suddaby, 2006). First, we transcribed the interviews and social media exchanges. Second, we open coded the data to extract instances that involved the use of ICT for managing external stakeholders. For example, 
when the project used Facebook to engage with the community and facilitate discussions, we coded it under the 'social mediatization' ICT form and coded the strategic use as 'engagement.' Similarly, when the project used computer generated traffic models to show different traffic flows and thereby persuade traffic authorities, we coded it under an ICT forms category named 'simulations' and coded the strategic use as 'persuasion.' Since both these strategic uses are based on the first dimension of power, we grouped them under the group code 'persuading' as both the above instances involved persuading the external stakeholders through discussions enabled by ICT. Thus, each instance observed was assigned to a category that was indicative of the data. This helped us arrive at conceptual categories for the forms of ICT and strategic uses of ICT. We discuss representative quotes that explain the categories allotted to them in the findings section. Third, the categories derived were enfolded in the existing literature of ICT in construction for triangulation and validation (Eisenhardt, 1989). The strategy categories were anchored in the dimensions of power theoretical framework as the use of organizational theories can infuse a more insightful and penetrating research agenda (Söderlund, 2011). Fourth, we used axial coding to put categories back together in new ways to provide novel insights (Strauss \& Corbin 1990). This axial coding helped us map the forms of ICT and the strategic use of ICT.

\section{Findings and Discussion}

In this section, ICT practices used for managing external stakeholder are categorized and their strategic uses are discussed by anchoring them in the dimensions of power framework. 


\section{Forms of ICT used in external stakeholder management}

We observed three uses of ICTs in the case - ICT as a practice of visualization, ICT as a practice of simulation and ICT as a practice of social mediatization. Each of these is discussed below and subsequently related to the three strategic practices of power that we have outlined.

\section{ICT as a practice of visualization}

The literature on ICT in construction supports the notion that ICT is used predominantly for visualization (Fazli et al., 2014). This visualization helps all stakeholders to comprehend the project better and facilitate constructive discussions. The project team used this strategically with the external stakeholders by assisting them to understand the construction complexities, addressing their concerns by using mutually agreeable solutions, thereby gaining their support for the project. The construction of the metro rail considered in this case study was changing the landscape of the city; for instance, some metro rail viaducts and piers needed to be constructed in locations that were in front of private property, potentially blocking views and depreciating asset values. The landowners who owned these houses and other properties were troubled by the proposed construction of the project and expressed their displeasure with the metro rail organization. In order to reduce inconvenience and gain community acceptance, the project team invited affected landowners to their office during the detailed design stage to show them graphical images and 3D CAD renderings of the viaducts and piers near their affected property. The project team visually demonstrated how the effects on properties changed with different draft layouts of pier locations; wherever possible, pier spans were adjusted to accommodate the interests of the landowners and improve the aesthetics of the metro's impact on the property. In this way the project team used ICT 
to address some of the concerns of the affected landowners. One of the managers of the metro rail organization remarked,

“They (the landowners) said ... if you built this way, we can't get out of our house ... or our view is blocked ... we addressed them collaboratively by showing a number of $3 D$ drawings ... Through this, we reduced the noise level"

The graphical prints and 3D CAD drawings of the metro rail piers acted as a visual aid for enabling discussions to arrive at feasible options to reduce the impact of the project on these property owners. The discussions resulted in the megaproject team adjusting the pier spans, thereby improving the visibility of the affected property and addressing critical concerns of the stakeholders in lands. The role of visualization to enhance participatory planning is emphasized in the literature. Leite (2016) note that stakeholders who are not well versed with the intricacies of a plan would be able to visualize the construction using such techniques. Visualization can also ensure deeper comprehension in communication and prepare the community for discussions and interactions (Kumar et al., 2016). Salter et al. (2007) record that the use of such visualizations in the form of GIS mapping to explain the changes in the landscape can increase stakeholders' understanding and thereby acceptance of the proposed plan.

\section{ICT as a practice of simulation}

ICT is used for enhancing visuals of the project by considering multiple scenarios through simulations or by using 3D renderings and morphed photographs as figurative representations in which digital data is altered or formulaically modified.

Construction of the elevated corridor of the metro rail project was planned along the median of the highway in an attempt to reduce overall land acquisition. However, this posed the challenge of managing highway traffic during construction periods. There 
were multiple regulations with which the metro rail project had to comply, such as working during hours when the highway traffic flows were low as well as proposing a diversion plan that afforded minimum disturbance to highway traffic. The project team was required to apply for permission as early as two months prior to the commencement of construction activities. The permission sought had to be obtained from the highway department, that owned the highway network, as well as the traffic police, that managed the traffic along the highway network. The project team used computer-generated animated traffic models which simulated traffic flows during different periods and used these to propose different scenarios for multiple traffic diversion plans. Only when the traffic police department and the highways department were satisfied that the disturbance caused would be minimum, was permission to divert traffic and start construction given. The use of computers enabled traffic simulations as a discussion tool was used to arrive at a traffic diversion plan which would cause minimum disturbance to the highway traffic and stakeholders in existing services.

The metro rail's operations would be powered by high voltage $25 \mathrm{KV}$ overhead electric lines and the airport authority expressed concerns about the amount of electronic interference that could be caused to aircraft flight systems during landing and take-off. The project team approached a technical institution for a detailed study of the electronic interference of the overhead electric lines on the aircraft equipment in different weather conditions. The computer-based simulation study carried out for this purpose indicated negligible electrical discharges which would not cause any significant electronic disturbance to the aircraft systems; consequently, the airport authority permitted further construction. Expert scientific knowledge was thus used as a legitimation device. The manager in charge of the airport metro rail project stretch said: 
"His (technical institution's professor) team measured wind turbulence in the metro path ... Then they simulated different wind patterns and weather conditions and said negligible electronic interference"

The city in which the megaproject is being built has a history of 400 years and houses many historical, cultural and heritage buildings. The metro rail initially proposed an elevated corridor in these areas of heritage significance in an attempt to reduce costs and time required for construction. A Public Interest Litigation (PIL) was filed in court against the metro rail organization for blocking the view of four heritage buildings and thereby changing the landscape of the city. Forsaking metro rail alignment near these heritage sites was not considered to be an option by megaproject managers as these areas housed significant populations, affording plentiful service opportunities. To construct the metro underground would cost six times more than the proposed elevated line. Strategically, to obtain funding from financers and support from the community for an underground plan, the project team used digitally modified images which rendered the elevated rail in front of the heritage buildings, showing how the streetscape would be altered deleteriously. The project team using these images, framed the proposition that going underground was the only option for sustaining the streetscape of the city. The project director of the metro rail project described it thus:

\footnotetext{
“The city doesn't have too many nice buildings [heritage buildings] ... We used trick photography to convince stakeholders regarding the change of plans to underground ... showing how each building would look if there was an elevated rail in front of it"
}

There were also rendered pictures and walk-in animations of stations targeted at the project community. Lange (1994) notes that both static and dynamic simulations can help communicate the contents of the proposal to the stakeholders and provide a common basis for discussions. 


\section{ICT as a practice of social mediatization}

Social media is a set of computer-mediated tools which enables the creation, circulation, sharing and exchange of information. It is different from the static world wide web as it enables two-way communication and is often called web 2.0. We see social media as a powerful ICT for engaging and managing external stakeholders.

The objectives of the social media campaign were enhancing the legitimation of the megaproject, despite the temporary incivilities and inconveniences that it might impose on the city residents and users. Organizational legitimacy is the 'generalized perception or assumption that the actions of an entity are desirable, proper, or appropriate within a social system' (Suchman, 1995). To try and achieve this outcome, many social media communications were addressed to the project community such as the following tweet on Twitter:

\section{Shuttle Services from Airport Metro Station from 1st October 2016 in an endeavour to cater to the public (Tweet by the metro rail organization on 30} September 2016)

The public relations office used social media to engage the project community by listening to their comments and suggestions and responding to them, thus building project management legitimacy. The community actively participated in discussions that varied from the features of the mobile application, availability of feeder bus services from metro rail stations to unconnected areas, roll out of bicycles on rent for last mile connectivity with stations and commuter homes, etc. On one of the suggestions of a Facebook user, the metro rail organization quickly responded as highlighted below,

"Please introduce EZlink ticket card like Singapore MRT" (Comment by a

Facebook user on 16 October 2017)

"Thank you for your suggestion. We will surely take this into consideration :)"

(Reply by the metro rail organization on 16 October 2017) 
Supporting this, Srivastava \& Pandey (2012) highlight that social media provides a way to connect with customers as organizations can scan customer's comments and concerns.

There were also frequent updates of the progress of the project through photos of work completed, in progress and live video streaming of milestone events.

Communications by the project team also included project advertisements, rendered pictures and walk-in animations of stations, their surroundings and metro rail coaches among others, that projected the metro rail as a safe, clean, environment-friendly and fast means of transportation beneficial to the city. There were also tweets which claimed that the metro rail project was a special project which was going to elevate the status of the city and change the lives of its inhabitants such as the one below.

"6 Possible ways how *** (metro rail) is going to change our lives" - Courtesy 104.8 FM (Tweet by the metro rail organization on 29 July 2015)

The visits of eminent personalities to the project sites were also reported in social media. Along with these project-based communications there were also nonproject-based communications such as the celebration of regional and national festivals, the organization's CSR activities, offering of complimentary rides to school children, etc. In an instance, a joy ride was provided to school children by the metro rail organization as highlighted in the tweet below,

"School students ride the Metro - *** (name of metro rail organization) along with Lions Club of *** (name of city) organized a Joy Ride" (Tweet by the metro rail organization on 19 August 2015)

Each of these many activities sought to weave an 'actor net' (Czarniawska, 2004) of enhanced legitimacy, incorporating various stakeholders in commitments to the megaproject. 
The project team also posted progress photos, celebrated regional and national festivals and publicized them in their social media page. Maresh-Fuehrer \& Smith (2016) claim that social media provides participation, openness, conversation, connectedness, and forms online communities quickly. These diverse roles of social media make it an important tool for community engagements in megaprojects, leading to community legitimation. Social media provides an advantage over other ICTs in engaging and managing external stakeholders because of its rapid delivery compared to print media and its unique ability to use different forms of media content such as photos, videos, and animations. It can also be used for participatory modelling of large infrastructure projects to reach a large number of people spread across the reach of the megaproject.

The specific instances of the use of ICTs to manage stakeholders that we have discussed in the findings section can be categorized into different practices of ICT as shown in Table 1.

Table 1. ICT enabled external stakeholder management strategies consolidated from the metro rail case

\begin{tabular}{|c|l|c|c|c|}
\hline $\begin{array}{c}\text { Sl. } \\
\text { No }\end{array}$ & \multicolumn{1}{|c|}{ Strategy Practice } & $\begin{array}{c}\text { Practices of } \\
\text { ICT }\end{array}$ & $\begin{array}{c}\text { Strategic use } \\
\text { category }\end{array}$ & $\begin{array}{c}\text { Power } \\
\text { dimension }\end{array}$ \\
\hline 1 & $\begin{array}{l}\text { Use of 3D CAD drawings to } \\
\text { adjust pier locations to improve } \\
\text { visibility of private property }\end{array}$ & Visualization & Persuading & $1^{\text {st }}$ \\
\hline 2 & $\begin{array}{l}\text { Community engagement and } \\
\text { discussions through social } \\
\text { media }\end{array}$ & $\begin{array}{c}\text { Social } \\
\text { Mediatization }\end{array}$ & Persuading & $1^{\text {st }}$ \\
\hline 3 & $\begin{array}{l}\text { Computer generated animated } \\
\text { traffic models to simulate traffic } \\
\text { flows during different periods } \\
\text { of time }\end{array}$ & Simulations & Persuading & $1^{\text {st }}$ \\
\hline 4 & $\begin{array}{l}\text { Computer based simulation } \\
\text { study of flight electronic } \\
\text { interference during different } \\
\text { weather conditions }\end{array}$ & Simulations & Persuading & $1^{\text {st }}$ \\
\hline 5 & $\begin{array}{l}\text { Digitally modified images to } \\
\text { show how elevated sections of } \\
\text { the metro rail would alter the }\end{array}$ & Simulations & Framing & $2^{\text {nd }}$ \\
\hline
\end{tabular}




\begin{tabular}{|c|c|c|c|c|}
\hline & $\begin{array}{l}\text { streetscape near the heritage } \\
\text { building }\end{array}$ & & & \\
\hline 6 & $\begin{array}{l}\text { Updates of progress of project } \\
\text { through social media photos } \\
\text { and live streaming }\end{array}$ & $\begin{array}{c}\text { Social } \\
\text { Mediatization }\end{array}$ & Framing & $2^{\text {nd }}$ \\
\hline 7 & $\begin{array}{l}\text { Project advertisements, } \\
\text { rendered pictures and walk-in } \\
\text { animations of coaches, stations } \\
\text { and surroundings }\end{array}$ & $\begin{array}{c}\text { Social } \\
\text { Mediatization }\end{array}$ & Framing & $2^{\text {nd }}$ \\
\hline 8 & $\begin{array}{l}\text { Social media tweets that claim } \\
\text { metro rail is going to elevate the } \\
\text { city and change the lives of its } \\
\text { inhabitants }\end{array}$ & $\begin{array}{c}\text { Social } \\
\text { Mediatization }\end{array}$ & Framing & $2^{\text {nd }}$ \\
\hline 9 & $\begin{array}{l}\text { Reporting of visits of eminent } \\
\text { personalities to project sites on } \\
\text { social media }\end{array}$ & $\begin{array}{c}\text { Social } \\
\text { Mediatization }\end{array}$ & Hegemonizing & $3^{\text {rd }}$ \\
\hline 10 & $\begin{array}{l}\text { Celebration of regional and } \\
\text { rational festivals }\end{array}$ & $\begin{array}{c}\text { Social } \\
\text { Mediatization }\end{array}$ & Hegemonizing & $3^{\text {rd }}$ \\
\hline 11 & $\begin{array}{l}\text { Update on CSR activities and } \\
\text { complimentary rides to school } \\
\text { children }\end{array}$ & $\begin{array}{c}\text { Social } \\
\text { Mediatization }\end{array}$ & Hegemonizing & $3^{\text {rd }}$ \\
\hline
\end{tabular}

\section{Strategic use of ICT in megaprojects}

We observed the use of ICT for three strategic purposes anchored within the dimensions of power theory (Lukes, 2005) as described below.

\section{ICT for Persuading Strategy - the first dimension of power}

ICT was used for enabling discussions with the affected external stakeholders thereby persuading them to favour the project by improving coordination and speeding the approval process. The ICT for persuading strategy often worked through negotiations, changing the content of the ICT artefact and subsequently the scope of activities according to the mutually agreed upon solution. Here, ICT was a resource to facilitate discussion and arrive at a mutual solution. Visualization ICT was used as a visual aid for enabling discussions with landowners whose property was affected due to the metro rail piers. Thus, the project team was able to arrive at a mutually acceptable solution and thereby reduce discomfort to the property owners. Through participatory modelling 
with the highway department using traffic simulations, the project team was able to create a traffic diversion plan which would cause minimum disturbance to the highway traffic. Similar instances were observed with the airport authority also, where simulations of discharges were used to convince them that there would be no electronic disturbances to the aircraft systems. The public relations office of the metro rail listened and responded to comments and queries raised on their social media pages and thereby engaged the project community. In these instances, ICTs became artefacts that allowed for better communication of technical information, building transparency and trust, enabling negotiations to move forward.

ICT visualization was a critical resource for the megaproject team, acting as a communication and discussion tool to persuade external stakeholders to support the project's goals. The dynamics of persuasion observed here constitute the first (overt) dimension of power as Avelino (2011) notes. The use of ICT and face-to-face interactions for briefings is mentioned as a 'hybrid briefing model' and has been seen to be beneficial for internal stakeholder engagements in the construction industry in the work of Chung et al. (2009). The persuading strategy is made possible with visualization, simulation and social mediatization. Along with possessing these ICT resources, the ability to operate them to facilitate discussions is also of critical importance here.

\section{ICT for Framing Strategy - the second dimension of power}

In any power relation there will be some parties for whom issues are legitimated while other parties will seek to delegitimize these or position other issues as more legitimate. ICT was used as a strategic tool to propagate certain issues and hide others. When a few members of the project community objected to the construction of the elevated metro 
rail near the heritage sites, thus altering the visual landscape of the city, the project chose to go underground so that these sites, which offered significant service opportunities, could still be connected. However, to gain acceptance of the increased cost of doing so, the project team used digitally morphed images to place an image of the elevated rail in front of these heritage buildings. Through this imaginative projection, the project team framed the argument that going underground was necessary for sustaining the landscape of the city and underplayed the fact that the financial commitments would rise six-fold, constituting a financial burden that would be levied on taxpayers and users for years to come. Similarly, when the metro rail project used advertisement videos, they represented the metro rail as safe, environment-friendly and fast, while hiding information such as the relatively high fares (compared to existing public transit systems) and the construction disturbances that the project would cause. The walk-in animations and rendered pictures of stations, their surroundings and rail coaches also portrayed a favourable visual ambiance for the project while hiding the negatives. The progress photos posted by the project team in their social media page represented only the positive news of the project and did not represent issues such as accidents, delays, and other criticisms. These instances, along with projected issues and hidden non-issues are tabulated in Table 2 below.

Table 2. Projected issues and Hidden non-issues enabled using ICT

\begin{tabular}{|l|l|l|l|}
\hline Sl.No & Instance & Projected issues & Hidden non-issues \\
\hline 1 & $\begin{array}{l}\text { Digitally morphed } \\
\text { images }\end{array}$ & $\begin{array}{l}\text { Underground metro } \\
\text { rail near heritage } \\
\text { buildings sustain the } \\
\text { landscape of the city }\end{array}$ & $\begin{array}{l}\text { Not constructing } \\
\text { this stretch is not an } \\
\text { option; Increased } \\
\text { fares; Use of tax- } \\
\text { payers money }\end{array}$ \\
\hline 2 & $\begin{array}{l}\text { Advertisements, 3D } \\
\text { rendering and walk-in } \\
\text { animations of stations, } \\
\text { its surroundings and } \\
\text { metro rail coaches }\end{array}$ & $\begin{array}{l}\text { Safe, environment } \\
\text { friendly, fast, } \\
\text { visually pleasing }\end{array}$ & $\begin{array}{l}\text { Increased fare and } \\
\text { the construction } \\
\text { disturbances that the } \\
\text { project would cause }\end{array}$ \\
\hline
\end{tabular}




\begin{tabular}{|l|l|l|l|}
\hline 3 & Social media discourse & $\begin{array}{l}\text { Social media posts of } \\
\text { metro rail as a } \\
\text { special project } \\
\text { elevating the city }\end{array}$ & $\begin{array}{l}\text { The project is one } \\
\text { among other } \\
\text { infrastructure } \\
\text { projects in the city }\end{array}$ \\
\hline 4 & Social media photos & $\begin{array}{l}\text { Shows only the } \\
\text { positive progress } \\
\text { photos of the project }\end{array}$ & $\begin{array}{l}\text { Photos of delays, } \\
\text { accidents and } \\
\text { criticism were } \\
\text { hidden }\end{array}$ \\
\hline
\end{tabular}

ICT was used as a framing tool to emphasize certain issues at the expense of others, a strategic use of ICT that enabled the project team to keep topics off the agenda (Bachrach \& Baratz, 1962) and not facilitate discussion on certain topics, in contrast with the 'persuading' strategy. With the use of the framing strategy, there is an implicit shaping of issues which are considered relevant (Fleming \& Spicer, 2014). Frames (Goffman, 1974) concern the way that something is presented to others, potentially affecting the actions and choices actors make. The dominant frame is an interpretation with the highest probability of being noticed, processed, and accepted by most people (Entman, 1993).

The strategic use of framing resonates with findings from Kornberger \& Clegg (2011), where the techno-rational discourse of the planner was substituted with the seductive, media-focused language of the strategist, thereby hiding certain issues. Similarly, Gil and Lundrigan (2012) mention how the 2012 London Olympics bid team represented and framed the megaproject as one of urban regeneration for one of the most deprived areas in London, to gain external stakeholder support for the project's wider legitimacy beyond a single mega-event. Framing seeks to keep issues off the agenda. Framing strategy is possible with simulation and social mediatization. This strategy contrasts with full and honest engagement with external stakeholders in projects (Nguyen et al., 2018) as project team keep topics off the agenda. While literature provides evidence for the use of construction specific ICTs, such as BIM and 
$\mathrm{CAD}$, for framing by hiding information and creating information asymmetry among internal stakeholders (Forsythe et al., 2015), little work exists on the use of these ICTs with external stakeholders. This may be because BIM and CAD drawings are considered internal documents in projects and are not expected to be shared with external stakeholders.

\section{ICT for Hegemonizing Strategy - the third dimension of power}

There is a great economy to that power which finds it unnecessary to intervene in existing relations because these relations already represent the issues that it seeks to reproduce. ICT in the form of social media was used to influence the project community by providing a vehicle for articulating their preferences, recursively feeding them back, subtly shaping concurrence, consensus and communication. The metro rail project celebrated regional and national occasions and festivals by publicizing them on their social media page. Similarly, the project's initiatives that supported the local community through repairing roads, churches, parks, conducting medical camps, hosting regional food carnivals as well as aiding rescue operations during a fire or building collapses were also mentioned in their social media pages. The pages also contained posts on how the metro rail was beneficial for the city, together with information on awards and recognitions conferred on the project. Through publicizing this news in social media, the project team created dominant discourses in favour of the project thereby amplifying the community's preferences subtly positioning brand advocacy. Social media communications offer more intense and more dynamic representation than simple management messages (Hassard \& Holliday, 1998). Such initiatives through social media encoded a new culture of national and regional pride, one subsequently reproduced through everyday activities (Edensor, 2002). The subtle strategy of shaping preferences and creating hegemony by aligning with what is already 
thought and experienced can be categorized as the third dimension of power (Lukes, 2005). This 'community pride' is mentioned as one of the benefits of a megaproject by Frey (2016) where people in the community enjoy recounting stories of the benefits achieved through these megaprojects. The social media page was strategically used to fuel community pride. The ability of social media to create positive effects on customers is supported by Laroche et al. (2013).

The ICT enabled strategies for external management observed from the case study of the metro rail megaproject and anchored in the dimensions of power (Lukes, 2005) are represented in Figure 2. Building upon the theoretical framework discussed in Figure 1, ICT for persuading strategy, anchored in the first dimension of power involves the strategic use of ICT to enable discussion and reach a mutual solution. ICT for framing strategy is anchored in the second dimension of power and involves the strategic use of ICT to keep topics off the agenda. ICT for hegemonizing strategy is anchored in the third dimension of power and involves the strategic use of ICT to shape preferences. 


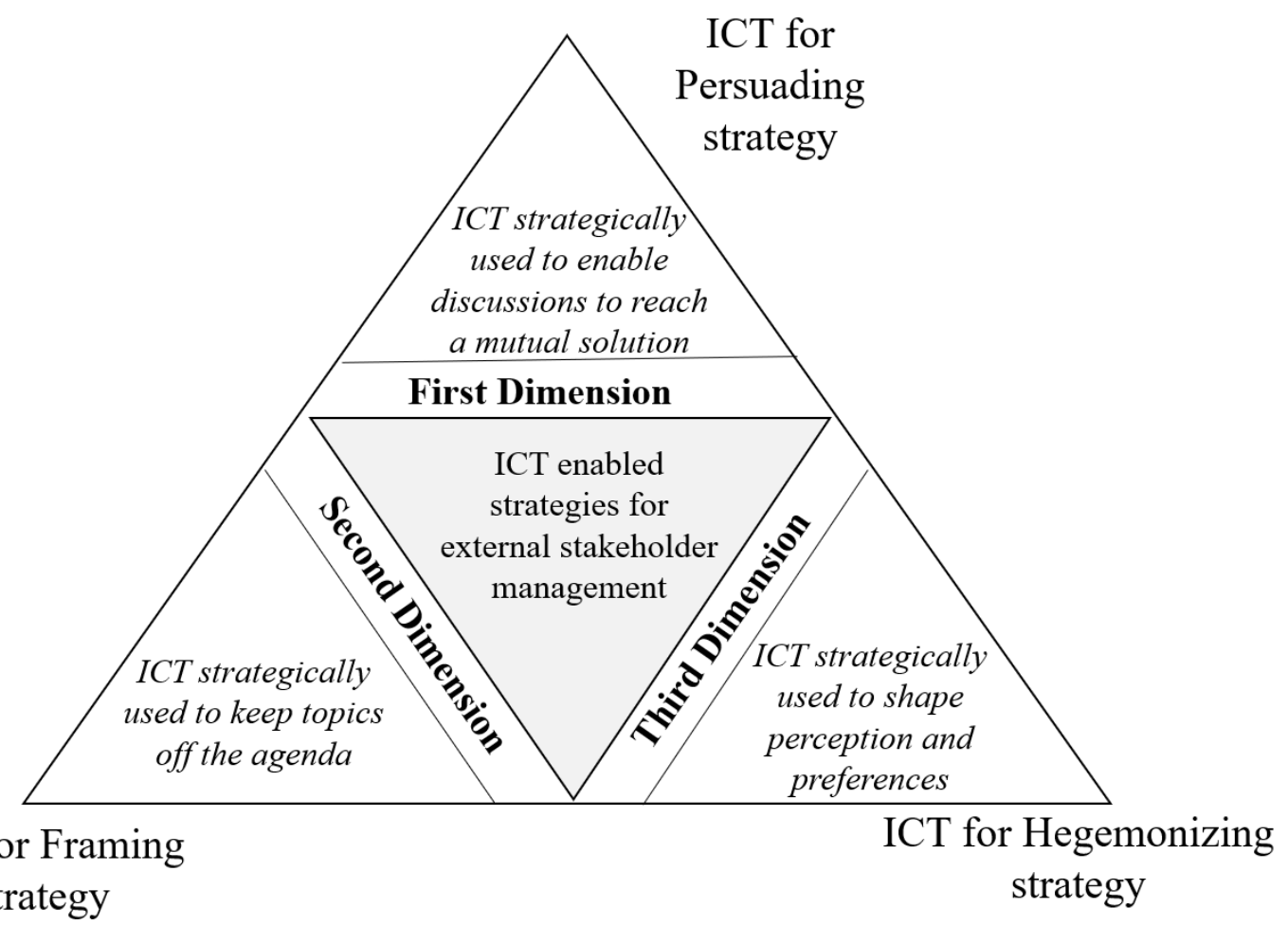

ICT for Framing strategy

ICT strategically perception and perception and

ICT for Hegemonizing strategy

Figure 2. ICT enabled strategies for external stakeholder management

The three external stakeholder management strategies that we observed can also be mapped to the three different forms of ICT as shown in Figure 3. Visualization was used in persuading landowners by changing the layout of piers. Making matter visual achieved in a few images what thousands of words could not: as the saying goes, every picture tells a story. Simulations and representations were used for persuading external stakeholders, such as the traffic department and the airport authority. Alternative conceptions of existing or future states of affairs are hard to make concrete in words whereas a digitally doctored image can make the frame that one wants to project evident. Simulation is an affordance that assists greatly by representing different scenarios to gain support for preferred outcomes by framing the project community through digitally morphed images, rendering and advertisements. Social mediatization was used as a discussion forum in which positive framing could occur that sought to persuade the project community by circulating news of the project while hiding 
negatives as well as creating dominant discourses that reflected and subtly skewed existing personal preferences. Here, we add social media's framing and hegemonizing affordances to its already discussed affordances of communication, collaboration, and knowledge sharing (Leonardi \& Vaast, 2017).

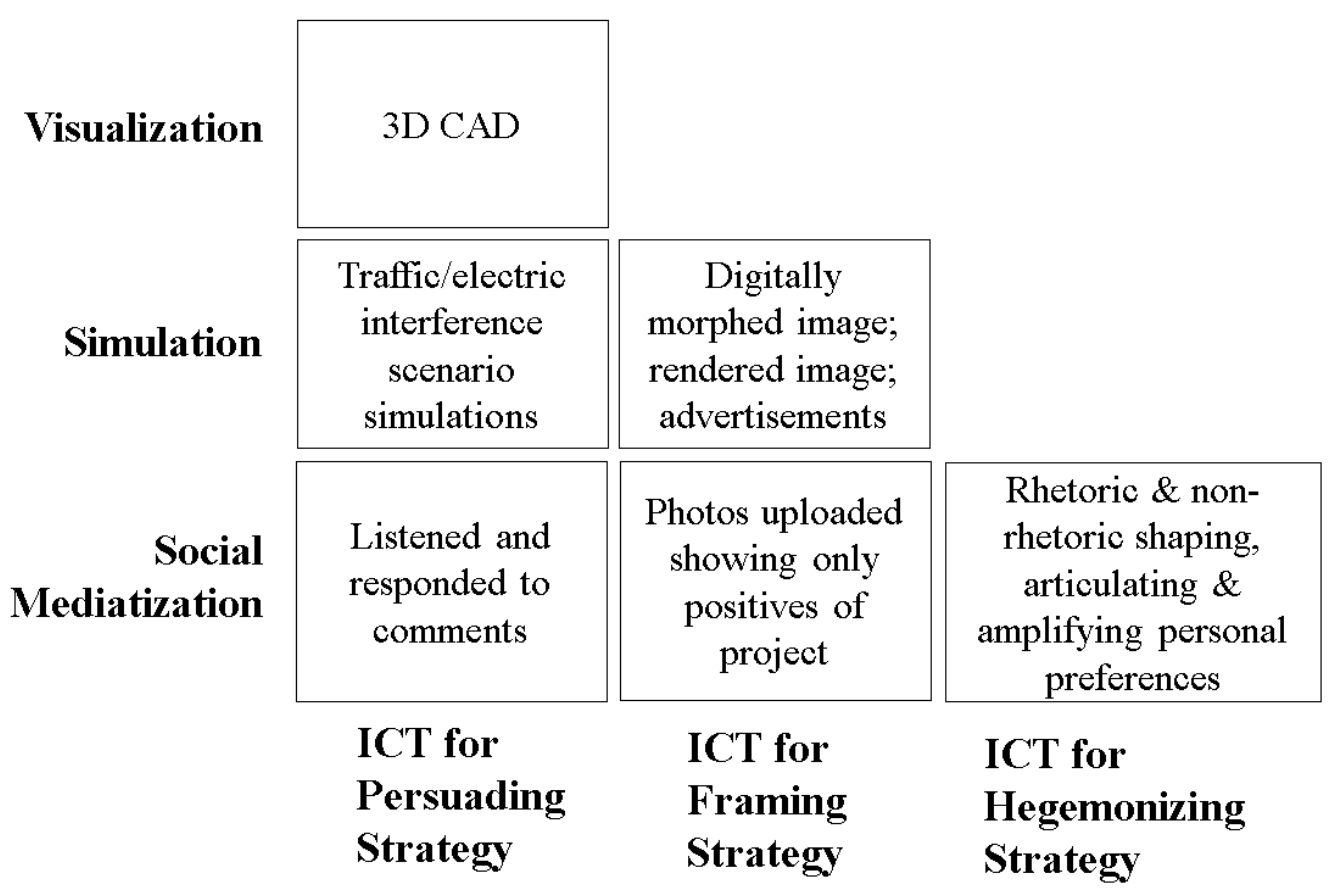

Figure 3. Mapping forms of ICT and its strategic use

As seen from Figure 3, ICT for persuading strategies involved visualization, simulation and social mediatization, wherein 3D CAD, traffic simulations and comments respectively were used to enable discussions and arrive at a mutual solution. ICT for framing strategies involved simulation ICT and social mediatization wherein digitally morphed images and positive photos respectively were used to keep topics off the agenda thereby preventing decisions from being made. ICT for hegemonizing strategies involved social mediatization wherein discourses shape external stakeholder preferences along the lines of the project's interests and an alternative to that interest is unimaginable. 
The Indian project context features low levels of technology adoption and most professionals prefer dealing with paper as opposed to digital equivalents (Mukherjee et al., 2019). Therefore, in this project's case and generally in the Indian context, ICTs such as BIM, Virtual Reality (VR), Augmented Reality (AR), Mixed Reality (MR), and other advanced applications were not employed to manage external stakeholders. However, anchored in the dimensions of power framework, this research helps us understand that ICTs employed to manage external stakeholders exist in the form of ICTs for persuading strategies, ICTs for framing strategies, and ICTs for hegemonizing strategies. This finding can be translated to other contexts. For example, in the case of the metro rail, we saw the use of 3D CAD visualization as ICT for persuading strategy, which can be BIM visualization in another project that has adopted BIM instead of 3D CAD. It is therefore possible, that other kinds of ICT tools can be used in other project settings around the world to persuade, frame and hegemonize, albeit through different dynamics.

\section{Conclusion}

This research was conducted to explore the wide range of strategic uses of ICT for managing external stakeholders in megaprojects. We argue that the sociomateriality perspective offers a suitable lens for exploring the diverse strategic uses of a particular ICT as determined by project team's particular need. The research demonstrates the applicability of the dimensions of power framework to explain the diverse intended and unintended use of ICT from a strategic perspective and make sense of its multiple affordances. We observed three ICT practices in use from the case study research carried out in a metro rail megaproject in India - visualization, simulation, and social mediatization, which we analysed in terms of the three dimensions of power. The 
strategic roles of ICTs were identified as persuading, framing and hegemonizing. Thus, this analysis based on the dimensions of power significantly augments our understanding of the diverse strategic use of ICT for managing external stakeholders. In our study, while the persuading strategy was possible with all forms of ICTs, framing strategy was possible with simulation and social mediatization. Hegemonizing strategy was possible only with the social mediatization practice.

While the construction management literature criticizes the construction industry for the poor adoption of ICTs compared to other industries, these studies are often limited to investigating the use of ICTs in project planning and monitoring. The research provides evidence of the prevalent use of ICTs from a strategic angle for managing external stakeholders. The use of these ICT enabled strategies is supported by top management to manage externalities in the form of external stakeholders, as the costs of stakeholder interventions are explicit and high. It must be noted that online deliberations, such as the use of social media to communicate, has issues of the digital divide as women and older generations of people are not adequately represented in such exercises (Albrecht, 2006). Therefore, use of social media would not be recommended for formal public consultation as some sections of the population may not be adequately reached; however, as a simulacrum of democratic participation it can be very effective. It is worth noting that even though ICTs were used for engaging and managing external stakeholders, they did not substitute for existing stakeholder engagement practices but rather only augmented them.

Theoretically, the study makes three contributions. First, while existing literature on ICTs in the construction industry mentions their strategic benefits such as improving the competitive advantage of internal stakeholders, this paper goes one step further and investigates the roles and uses of ICTs for engaging and managing external 
stakeholders. Second, this research adds social media to the current list of ICTs employed in project management, especially for managing external stakeholders. We thus add social media to the earlier list (Collinge, 2018) of project artefacts such as drawings, digital imagery, physical objects, etc., that are effective for stakeholder engagement. Also, the research adds framing and hegemonizing affordances of social media to the already existing affordances of communication, collaboration and knowledge sharing (Leonardi \& Vaast, 2017).

The research contributes to practice and augments extant knowledge on the use of ICTs to manage stakeholders in three ways. First, the categorization of ICTs according to their strategic use offers a framework to analyse strategic use of ICTs employed in practice to manage external stakeholders. Second, while the current literature on the strategic use of ICT in construction project management stresses the persuading role of ICT (Chung et al., 2009; Mahalingam et al., 2010), the framing and hegemonizing roles are underplayed and presents immense opportunities for managing external stakeholders. The paper contributes to existing knowledge of affordances of ICTs by discussing the use of ICTs in facilitating these two strategies as well. Finally, because of the unique advantages of social media, such as quicker delivery, wider reach, ability to use different rhetoric or non-rhetoric contents, and its use for persuading, framing, and hegemonizing strategies, we propose it as a significant tool for external stakeholder engagement. To public policy, we highlight that a proper framework for online community engagement is necessary as most infrastructure megaprojects currently operate a social media page. The objectives and practice of using the social media page should be clearly spelt out and regulated.

One of the limitations of this study is the generalizability of the findings because of the use of a single case study. However, social media are universally similar 
technologies and are capable of being translated into applications almost anywhere. A contextual limitation of this study is the absence of proper guidelines for online engagement in India; elsewhere the context might be different. Future studies can validate and extend our observations by conducting studies in different projects in other areas of the world. Such studies can explore whether there are any negative implications of online community engagements, such as affording additional opportunities for project litigation as the multiplicity of messages fail to cohere, or as more information that in some cases may implicate the project, are made available to stakeholders.

The strategic use of ICT to manage external stakeholders offers many other directions for future studies. When major projects own and operate social media pages to update the project community of the progress, their role in managing external stakeholders through persuading, framing and hegemonizing cannot be ignored. More in depth studies need to be carried out on each of these diverse strategic roles of social media. The ICTs employed in the project case considered were commonly available tools and not construction industry specific which shows the affordances of these sociomaterial technologies. Sophisticated ICTs such as BIM, virtual reality (VR), augmented reality (AR), or mixed reality (MR) can offer considerable scope for external stakeholder engagement in megaprojects in the future which needs to be investigated. It is also worth investigating how these different ICTs work in tandem to achieve external stakeholder management in megaprojects and what ICT forms and strategies work for different stakeholder groups.

\section{References}

Albrecht, S., 2006. Whose voice is heard in online deliberation: A study of participation and representation in political debates on the internet. Information, Community and Society, 9(1), 62-82. 
Alsafouri, S., and Ayer, S. K., 2018. Review of ICT Implementations for Facilitating Information Flow between Virtual Models and Construction Project Sites. Automation in Construction, 86, 176-189.

Arashpour, M., et al., 2017. Optimizing decisions in advanced manufacturing of prefabricated products: Theorizing supply chain configurations in off-site construction. Automation in Construction, 84, 146-153

Arts, B., and Van Tatenhove, J., 2004. Policy and power: A conceptual framework between the 'old'and 'new'policy idioms. Policy sciences, 37(3-4), 339-356.

Atkin, B., and Skitmore, M., 2008. Stakeholder management in construction. Construction Management and Economics, 26(6), 549-552.

Avelino, F., and Rotmans, J., 2009. Power in transition: an interdisciplinary framework to study power in relation to structural change. European journal of social theory, 12(4), 543-569.

Avelino, F., 2011. Power in transition: empowering discourses on sustainability transitions. Thesis (PhD). Erasmus University Rotterdam.

Bansal, P., Smith, W. K., and Vaara, E., 2018. New ways of seeing through qualitative research. Academy of Management Journal, 61(4), 1189-1195

Barad, K., 2003. Posthumanist performativity: Toward an understanding of how matter comes to matter. Signs: Journal of women in culture and society, 28(3), 801-831.

Barley, S. R., 1986. Technology as an occasion for structuring: evidence from observations of CT scanners and the social order of radiology departments, Administrative Science Quarterly, 31, 78-108

Bachrach, P., and Baratz, M.S., 1962. Two faces of power. American Political Science Review, 56, 947-952 
Chan, P. W., 2020. Revisiting basics: theoretically-grounded interesting research that addresses challenges that matter. Construction Management Economics, 38(1), 110

Chung, J. K., Kumaraswamy, M. M., and Palaneeswaran, E., 2009. Improving megaproject briefing through enhanced collaboration with ICT. Automation in construction, 18(7), 966-974.

Clegg, S. R., 1989. Frameworks of power. London: Sage.

Clegg, S. R., Pitelis, C., Schweitzer, J. and Whittle, A., 2020. Strategy: Theory \& Practice, London: Sage.

Collinge, W. H., 2018. Exploring construction project design as multimodal social semiotic practice. Social Semiotics, 1-19.

Czarniawska, B., 2004. On time, space, and action nets. Organization, 11(6), 773-791.

Dahl, R. A., 1957. The concept of power. Behavioral science, 2(3), 201-215.

Davies, K. K., et al., 2015. Improving ecosystem service frameworks to address wicked problems. Ecology and Society, 20(2), 1-11.

Designingbuildings.co.uk., 2017. Information and communications technology in construction. Available from:

https://www.designingbuildings.co.uk/wiki/Information_and_communications_tech nology_in_construction [Accessed 10 February 2018].

Dyer Jr, W. G., and Wilkins, A. L., 1991. Better stories, not better constructs, to generate better theory: A rejoinder to Eisenhardt. Academy of management review, 16(3), 613-619.

Edensor, T., 2002. National identity, popular culture and everyday life. London, UK:

Bloomsbury Publishing. 
Eisenhardt, K. M., 1989. Building theories from case study research. Academy of Management Review, 144, 532-550.

El-Ghandour, W., and Al-Hussein, M. 2004. Survey of information technology applications in construction. Construction innovation, 4(2), 83-98.

Entman, R. M., 1993. Framing: Toward clarification of a fractured paradigm. Journal of communication, 43(4), 51-58.

Evers, M., et al., 2016. Collaborative decision making in sustainable flood risk management: a socio-technical approach and tools for participatory governance. Environmental Science \& Policy, 55, 335-344.

Fazli, A, et al., 2014. Appraising effectiveness of Building Information Modelling (BIM) in project management, Procedia Technology, 16, 1116-1125.

Fleming, P., and Spicer, A., 2014. Power in management and organization science. The Academy of Management Annals, 8(1), 237-298.

Flyvbjerg, B., Bruzelius, N., and Rothengatter, W., 2003. Megaprojects and risk: An anatomy of ambition. London, UK: Cambridge University Press.

Flyvbjerg, B., 2006. Five Misunderstandings About Case-Study Research, Qualitative Inquiry, 12(2), 219-245.

Flyvbjerg, B., 2014. What You Should Know about Megaprojects and Why: An overview. Project Management Journal, 45(2), 6-19

Forsythe, P., Sankaran, S., and Biesenthal, C., 2015. How far can BIM reduce information asymmetry in the Australian construction context. Project Management Journal, 46(3), 75-87.

Frey, T., 2016. Megaprojects set to explode to $24 \%$ of global GDP within a decade. Available from http://www.futuristspeaker.com/job-opportunities/megaprojects-setto-explode-to-24-of-global-gdp-within-a-decade/ [Accessed on 15 February 2018]. 
Frick, K. T., 2008. The cost of the technological sublime: Daring ingenuity and the new San Francisco-Oakland Bay Bridge. In H. Priemus, B. Flyvbjerg, and B. van Wee, eds. Decision-making on mega-projects: Cost-benefit analysis, planning and innovation. Cheltenham, UK: Edward Elgar, 239-262.

Gaventa, J., 1980. Power and powerlessness. Urbana, USA: University of Illinois Press.

Giezen, M., 2012. Navigating mega projects through complexity and uncertainty: strategic and adaptive capacity in planning and decision-making. Thesis ( $\mathrm{PhD})$. University of Amsterdam.

Gil, N. A, and Lundrigan, C., 2012. The leadership and governance of megaprojects. Manchester: Manchester University.

Gil, N. A., 2015. Sustaining Highly-Fragile Collaborations: A Study of Planning Mega Infrastructure Projects in the UK. Manchester, UK: University of Manchester.

Goffman, E., 1974. Frame analysis: An essay on the organization of experience. Cambridge, US: Harvard University Press.

Gooch, G., and Huitema, D., 2008. Participation in water management: theory and practice. The adaptiveness of IWRM: analysing European IWRM research. London, UK: IWA Publishing

Hardy, C., 1996. Understanding power: bringing about strategic change. British Journal of Management, 7(1), 3-16.

Hassard, J., and Holliday, R., eds., 1998. Organization-representation: Work and organizations in popular culture. London, UK: Sage.

Haugaard, M., 2010. Power: a 'family resemblance'concept. European Journal of Cultural Studies, 13(4), 419-438. 
Hedelin, B., et al., 2017. Participatory modelling for sustainable development: Key issues derived from five cases of natural resource and disaster risk management. Environmental Science \& Policy, 76, 185-196.

Hosseini, R., et al., 2013. Approaches of implementing ICT technologies within the construction industry. Australasian Journal of Construction Economics and Building-Conference Series, 1(2), 1-12.

Jordhus-Lier, D., 2015. Community resistance to megaprojects: The case of the N2 Gateway project in Joe Slovo informal settlement, Cape Town. Habitat International, 45, 169-176.

Kornberger, M., and Clegg, S., 2011. Strategy as performative practice: The case of Sydney 2030. Strategic Organization, 9(2), 136-162.

Kumar, A., et al., 2016. Using 'design thinking' to enhance urban re-development: a case study from India. Engineering Project Organization Journal, 6(2-4), 155-165.

Lamprou, E., Mitev, N., and Doolin, B., 2014. Information systems and assemblages. Working Conference on Information Systems and Organizations. Berlin, Germany: Springer.

Lange, E., 1994. Integration of computerized visual simulation and visual assessment in environmental planning. Landscape and urban planning, 30(1-2), 99-112.

Laroche, M., Habibi, M. R., and Richard, M. O., 2013. To be or not to be in social media: How brand loyalty is affected by social media. International Journal of Information Management, 33(1), 76-82.

Lehtonen, M., 2019. Ecological economics and opening up of megaproject appraisal: lessons from megaproject scholarship and topics for a research programme. Ecological Economics, 159, 148-156. 
Leite, F., et al., 2016. Visualization, information modeling, and simulation: Grand challenges in the construction industry. Journal of Computing in Civil Engineering, 30(6), 04016035.

Leonardi, P. M., and Barley, S. R., 2008. Materiality and change: Challenges to building better theory about technology and organizing. Information and organization, 18(3), 159-176.

Leonardi, P. M., and Barley, S. R., 2010. What's under construction here? Social action, materiality, and power in constructivist studies of technology and organizing. Academy of Management Annals, 4(1), 1-51.

Leonardi, P. M., and Vaast, E., 2017. Social media and their affordances for organizing: A review and agenda for research. Academy of Management Annals, 11(1), 150188.

Little, R. G., 2011. The emerging role of public-private partnerships in megaproject delivery. Public Works Management \& Policy, 16(3), 240-249.

Lukes, S., 1974. Power: A radical view. London, UK: Macmillan.

Lukes, S., 2005. Power. A Radical View. New York, USA: MacMillan.

Lundin, R. A., and Steinthórsson, R. S., 2003. Studying organizations as temporary. Scandinavian Journal of Management, 19(2), 233-250

Mahalingam, A., Kashyap, R., and Mahajan, C., 2010. An evaluation of the applicability of 4D CAD on construction projects. Automation in Construction, 19(2), 148-159.

Mahalingam, A., and Ninan, J., 2019. External Stakeholder Management in Megaprojects-A Framework of Strategies and Power in Practice. In P. Chinowsky and J. Taylor, eds. Proceedings of the Engineering Project Organization 
Conference. 25-27 June 2019 Colorado: Engineering Project Organization Society (EPOS), 1-22.

Maresh-Fuehrer, M. M., and Smith, R., 2016. Social media mapping innovations for crisis prevention, response, and evaluation. Computers in Human Behavior, 54, 620-629.

Mukherjee, K. K., Iyer, K. C., and Sawhney, A., 2019. Sector-level objectives and associated inhibiting and enabling factors for the Indian real estate sector from a process standardisation perspective. Property Management. 37(3), 367-389

Nandyala, C. S., and Kim, H. K., 2016. Green IoT agriculture and healthcare application (GAHA). International Journal of Smart Home, 10(4), 289-300.

Ninan, J., Mahalingam, A., and Clegg, S., 2019. External Stakeholder Management Strategies and Resources in Megaprojects: An Organizational Power Perspective. Project Management Journal, 50(6), 625-640.

Nguyen, T. H. D., Chileshe, N., and Rameezdeen, R., 2018. External stakeholder strategic actions in construction projects: a Vietnamese study. Construction Management and Economics, 36(8), 443-458.

Nitithamyong, P., and Skibniewski, M. J., 2006. Success/failure factors and performance measures of web-based construction project management systems: professionals' viewpoint. Journal of construction engineering and management, 132(1), 80-87.

Oladapo, A. A., 2007. An investigation into the use of ICT in the Nigerian construction industry. Journal of Information Technology in Construction, 12(18), 261-277.

Orlikowski, W. J., 2010. The sociomateriality of organisational life: considering technology in management research. Cambridge Journal of Economics, 34(1), 125141. 
Orlikowski, W. J. and Iacono, C. S., 2001. Desperately seeking the "IT'” in IT research — a call to theorizing the IT artifact, Information Systems Research, 12(2), $121-34$

Orlikowski, W.J., and Scott, S.V., 2008. Sociomateriality: Challenging the Separation of Technology, Work and Organization. Academy of Management Annals 2(1), 433-474.

Ragin, C. C., 1992. "Casing” and the process of social inquiry. In C. C. Ragin \& H. S. Becker, eds. What is a case? Exploring the foundations of social inquiry. Cambridge, UK: Cambridge University Press, 217-226.

Salter, J. D., et al., 2009. The digital workshop: Exploring the use of interactive and immersive visualisation tools in participatory planning. Journal of environmental management, 90(6), 2090-2101.

Sassen, S., 2012. Interactions of the Technical and the Social: Digital Formations of the Powerful and the Powerless. Information, Communication \& Society, 15(4), 455478.

Schattschneider, E. E., 1960. The Semisovereign People. A Realist's View of Democracy in America. New York, USA: Holt, Rinehart and Winston.

Söderlund, J., 2011. Pluralism in project management: navigating the crossroads of specialization and fragmentation. International Journal of Management Reviews, 13(2), 153-176.

Srivastava, A., and Pandey, K. M., 2013. Social media marketing: an impeccable approach to e-commerce. Management Insight, 8(2), 1-7.

Stake, R. E., 2005. Qualitative case studies. In N. K. Denzin \& Y. S. Lincoln, eds. The SAGE handbook of qualitative research (3rd ed.) Thousand Oaks, CA: SAGE, 443-466. 
Strauss, A., and Corbin, J. M., 1990. Basics of qualitative research: Grounded theory procedures and techniques. Newberry Park: Sage.

Styhre, A., 2017. Thinking about materiality: the value of a construction management and engineering view. Construction management and economics, 35(1-2), 35-44

Suchman, L., 2007. Human-machine reconfigurations: Plans and situated actions. New York, USA: Cambridge University Press.

Suchman, M. C., 1995. Managing legitimacy: Strategic and institutional approaches. Academy of management review, 20(3), 571-610.

Suddaby, R., 2006. From the editors: what grounded theory is not. Academy of Management Journal, 49(4), 633-642.

Taylor, J. E., \& Levitt, R., 2007. Innovation alignment and project network dynamics: An integrative model for change. Project management journal, 38(3), 22-35.

van den Ende, L., and van Marrewijk, A., 2019. Teargas, taboo and transformation: A neo-institutional study of community resistance and the struggle to legitimize subway projects in Amsterdam 1960-2018. International Journal of Project Management, 37(2), 331-346.

Wagner, E. L., Moll, J., and Newell, S., 2011. Accounting logics, reconfiguration of ERP systems and the emergence of new accounting practices: A sociomaterial perspective. Management Accounting Research, 22(3), 181-197.

Walker, D. H., Bourne, L. M., and Shelley, A., 2008. Influence, stakeholder mapping and visualization. Construction Management and Economics, 26(6), 645-658.

Weber, M., 1947. The theory of social and economic organization. New York: Free Press.

Yin, R., 1984. Case study research: Design and methods, New York, USA: Sage. 